\title{
MENJADI PELAYAN TUHAN \\ YANG SETIA DAN BERTANGGUNG JAWAB
}

\author{
SULASTRI \\ INSTITUT AGAMA KRISTEN NEGERI (IAKN) TORAJA
}

lastriaci11298@gmail.com

\begin{abstract}
Abstrak
Pelayanan adalah panggilan yang harus ditunaikann oleh semua orang percaya. Melayani Tuhan adalah sikap lewat pikiran, perkataan dan perbuatan yang sesuai dengan keinginan Tuhan. Memberi tempat bagi Tuhan untuk berkarya dalam kehidupan adalah bagian dari pelayanan kepada Tuhan. Pelayanan tidak harus dilakukan di dalam gereja atau berbicara di depan orang banyak, tapi pelayanan juga adalah tentang sikap mendisiplinkan diri dan melakukan keinginan Tuhan dalam hidup kita.

Pelayan Tuhan juga dapat diartikan sebagai seorang pemimpin. Pemimpin dan kepemimpinan adalah dua hal yang memiliki perbedaan. Pemimpin adalah seseorang yang melakukan fungsi memimpin, sementara kepemimpinan adalah proses dan tindakan pemimpin untuk memimpin.

Dalam penulisan ini, memiliki tujuan untuk mengetahui bagaimana pentingnya pekerjaan dan teladan seorang pelayan Tuhan kepada Tuhan dan jemaat. seorang pelayan, harus terlibat dalam pelayanan dalam keluarga, gereja, sekolah, masyarakat, dan bahkan negara. Pekerjaan yang patut diteladani yang tidak mengenal lelah, batas dan waktu adalah menggembalakan domba.
\end{abstract}

\section{Pendahuluan}

Setia atau kesetiaan bisa diartikan sebagai berpegang teguh, taat pada janji. Loyalitas seorang pelayan sangat berpengaruh pada proses pelayanan yang dilakukan. Tanggung jawab adalah hal yang wajib dilakukan, rasa tanggung jawab seorang yang percaya kepada Tuhan dan bahkan seorang pelayan Tuhan adalah dengan cara selalu bersyukur dan menjaga hikmat yang telah diberikan-Nya dan dengan cara itu, kita menaati segala perintah Tuhan dan menjauhi larangan-Nya. Sebelum kita melangkah pada kesediaan dan tanggung jawab terhadap orang lain, kita harus terlebih dahulu setia dan bertanggung jawab pada diri sendiri. Untuk menjadi pelayan Tuhan yang setia dan bertanggung jawab, terkadang itu terasa sulit kita lakukan. Pelayanan yang di lakukan kepada Tuhan adalah panggilan bagi setiap manusia, terkhusus umat kristiani. Melayani Tuhan dapat dilakukan dengan berbagai cara dan di berbagai tempat. Melayani Tuhan tidak harus dalam lingkup gereja, atau di hadapan masyarakat. Melayani Tuhan dimulai dari sikap rendah hati dan hidup dalam kehendak Tuhan sehingga menyenangkan hati Tuhan.

\section{Tujuan dan Manfaat}

Penulisan jurnal ini bertujuan untuk mendiskripsikan dan mengedukasi pelayan dan hakitat sebuah pelayanan. Menjadi pelayan Tuhan yang setia dan bertanggung jawab bukan hanya diperuntukkan untuk para pelayan gereja atau masyarkat, tetapi juga untuk diri sendiri dalam pelayanan pribadi kepada Tuhan. Di dalam konteks pelayanan pribadi kepada Tuhan seperti yang telah digambarkan pada bagian abstrak juga membutuhkan tanggung jawab dan kesetiaan yang besar terhadap diri sendiri dan terhadap Tuhan. Sikap diri yang melakukan keinginan Tuhan dalam diri harus dilakukan dengan tanggung jawab dan kesetiaan agar tidak mudah berpaling. Ada banyak hal yang dapat membuat pelayanan kepada Tuhan menjadi redup, di antaranya rasa bosan, pengaruh lingkungan dan lain-lain. Oleh karena itu tanggung jawab dan kesetiaan harus tetap menjadi prioritas tinggi dalam pelayanan agar tetap menjadi teladan dan menyenangkan hati Tuhan. Bukankah pelayan juga harus menjadi teladan?. Dalam Konteks pelayan jemaat dan masyarakat, tentu tanggung jawab dan kesetiaan menjadi lebih besar lagi. Tanggung jawab kepada masyarakat harus dilakukan layaknya seorang gembala yang bertanggung jawab terhadap gembalaannya agar tidak sesat dan dapat selalu kembali ke kandangnya. Ada begitu banyak jemaat yang harus 
digembalakan oleh pelayan jemaat, dan menjadi tanggung jawab bagi pelayan untuk memberikan edukasi dan konseling kepada jemaat agar selalu hidup berdasarkan kehendak Tuhan. Selain tanggung jawab, kesetiaan juga menjadi hal prioritas, karena menjadi pelayan berarti menghadapi banyak karakter dalam masyarakat dan jemaat. berdasarkan pada empiris, beberapa pelayan Tuhan akhirnya mengundurkan diri karena tidak sanggup menghadapi karakter jemaat. Tidak hanya sampai di sini, pelayan Tuhan juga tidak selalu memberi pelayanan di tempat yang sama, tetapi di tempat yang berbeda.

\section{Pembahasan}

Tanggung jawab adalah kesadaran orang akan kewajiban untuk menanggung segala akibat dari sesuatu yang diperbuatnya. Bertanggung jawab atas apa yang dilakukan juga bisa berarti menjaga dengan sebaik-baiknya agar segala yang sedang atau telah diperbuat dapat selalu terpelihara dengan baik. Sejak awal penciptaan manusia sudah diberikan tanggung jawab masing-masing. ${ }^{1}$ Jadi, dalam perjalanan pelayanan terhadap Tuhan, seseorang harus dengan totalitas agar pelayanan yang dilakukannya dapat terpelihara sempurna dalam sepanjang perjalanan hidup.

Ancaman tidak selalu dalam bentuk yang menakutkan, tetapi ancaman juga kadang tampil sebagai sesuatu yang mempesona sehingga dapat menggoga seseorang untuk mengejarnya dan berpaling dari apa yang sedang dilakukannya. Kedua hal tersebut adalah realitas yang pasti dijumpai dalam pelayanan, ada begitu banyak ancaman dan godaan yang dapat membuat manusia berpaling apabila tanggung jawab dan kesetiaanya tidak kokoh. Sebagai seorang pelayan Tuhan atau pemimpin, pasti banyak tantangan yang akan dihadapi yang berkaitan dengan kepemimpinan baik dalam masyarakat secara keseluruhan maukun kepada gereja. ${ }^{2}$

Bukanlah hal mudah menjadi seorang pelayan. Kesetiaan dan tanggung jawab sangat berpengaruh pada pelayanan yang dilakukan. Gambaran sebagai seorang pelayan yaitu dengan melihat apa yang dilakukan Tuhan Yesus sendiri. Melayani dengan suka rela tanpa mengharapkan imbalan, tidak menyombongkan diri dengan tindakan apa yang telah dilakukan. Melalui pelayanan yang dilakukan Yesus sendiri kepada manusia dengan berkorban di atas kayu salib dan tanpa mengharapkan imbalan dari manusia, yakni pelayanan dengan tulus, untuk menghapuskan dosa yang telah melekat dalam diri manusia yang berdosa. ${ }^{3}$ Pelayan yang setia dan bertanggung jawab, harus meneladani akan hal yang dilakukan Tuhan Yesus sendiri. Tidak memandang keberadaan dan latar belakang jemaat, melainkan harus mampu menerima kehidupan jemaat apa adanya.

Setia dan bertanggung jawab harus dimulai dari diri sendiri, melalui kisah Yesus Kristus yang menjadi teladan didalam kehidupan kita dengan tetap berpegang pada kebenaran firman Tuhan. Salah satu yang patut diteladani dari kehidupan Yesus adalah mengasihi musuh kita, dalam artian jangan ada menyimpan dendam atau benci kepada sesama kita ketika ia perna menyakiti hati kita. ${ }^{4}$ Kemudian dikembangkangkan melalui kehidupan keluarga, jemaat, masyarakat dan bahkan kepada negara. Setia dengan tidak pernah bosan akan pelayanan yang dilakukan, dan terhadap kehidupan yang dihadapi. Seorang pelayan harus mengetahui bahwa dalam pelayanan yang diangkat kepada Tuhan, bukan berarti bebas dari masalah kehidupan. Namun, semakin teguh melayani dengan ketekunan maka semakin banyak pergumulan dan rintanagan yang kita hadapi. Olehnya itu, karena telah mengetahui akan banyak rintangan yang akan di hadapi dalam mengangkat peayanan, maka harus semangat dan tetap mengandalkan Tuhan dalam kehidupan pelayanan.

Rasa bosan, lelah, takut, khawatir, dan persoalan hidup adalah musuh terbesar seorang pelayan Tuhan. keinginan untuk menikmati berbagai tawaran dunia yang menggiurkan, keinginan untuk lebih leluasa dalam pergaulan, mendapat ancaman dari kaum radikal, atau adanya tekanan hidup harus dihindari atas

\footnotetext{
${ }^{1}$ Rannu Sanderan, “Jabatan Gerejawi Dan Peran Perempuan Dalam Pelayanan Gereja” (2021), https://osf.io/jtcag.

2 Rannu Sanderan, "Stratifikasi Sosial Kepemimpinan Tradisional Dalam Dinamika Demokrasi Modern” (2021), https://osf.io/63yaj/.

${ }^{3}$ Rannu Sanderan, “Disiplin Asketisme Dan Harmoni Kontribusi Disiplin Diri Bagi Pengembangan Pendidikan Kristen" (2021), https://osf.io/frsnz/.

${ }^{4}$ Rannu Sanderan, "EXEMPLARY: Menemukenali Kunci Pendidikan Kristen Bagi Anak Dalam Keluarga Dan

Pembelajaran Agama Di Sekolah" (2021), https://osf.io/bntrk/.
} 
kesadaran tanggung jawab, dan kesetiaan serta tentang cara melibatkan Tuhan dan meminta hikmat agar dapat semakin bijaksana dalam mengemban tugas panggilan. Tuhan yang menjadi manusia dan yang menjadi penopang yang manusia libatkan dalam kehidupan sehari-hari. ${ }^{5}$ Memang secara manusiawi hal tersebut sangat sulit dilakukan dalam kapasitas sebagai manusia yang sejatinya adalah penuh keterbatasan, namun bila Tuhan yang bekerja dan menopang maka segala persoalan dalam misi pelayanan dapat dilalui. Belajar dari Rasul Paulus yang meski diperhadapkan dengan berbagai persoalan dalam perjalanan misinya, tetapi pelayanannya tidak berhenti dan tidak dibatasi oleh dinding penjara sehingga jemaat yang dirintis dan dibangunnya dapat semakin dewasa dalam pelayanan kepada Tuhan. Bukankah Rasul Paulus adalah manusia biasa yang sama dengan kita? Tetapi kunci keberhasilannya adalah karena tanggung jawab dan kesetiaan yang penuh kepada Tuhan.

\section{Kesimpulan dan Saran}

Telah diuraikan dengan singkat tentang pelayanan tidak harus menjadi pembicara di gereja, atau di depan banyak orang, tetapi pelayanan adalah panggilan bagi semua orang percaya yang harus diembannya dalam sepanjang hidupnya. Namun, di dalam perjalanan pelayanan tentu diperhadapkan pada berbagai dinamika dan tantangan bahkan resiko yang mungkin terjadi. Selain melawan berbagai godaan dan ancaman di sekitar, yang pertama harus ditaklukkan adalah diri sendiri. Ditaklukkan artinya harus dikendalikan agar tidak diombang-ambingkan oleh berbagai situasi menggiurkan di sekitar kita.

Menjadi seorang pelayan Tuhan, harus mampu setia dan bertanggung jawab dalam melaksanakan tugas dan pelayanan. Olehnya itu jangan ragukan kasih Tuhan dalam pelayananmu, yakinlah bahwa Tuhan selalu melimpahkan kasihnya, tetap andalkan Tuhan dalam menjalani proses unruk mengankat tugas dan pelayanan.

\footnotetext{
${ }^{5}$ Rannu Sanderan, “Budaya Akrhaik Dalam Aktualisasi Agama Modern” (2021), https://osf.io/v5u8e/.
} 


\section{Referensi}

Rannu Sanderan. "Budaya Akrhaik Dalam Aktualisasi Agama Modern” (2021). https://osf.io/v5u8e/.

. "Disiplin Asketisme Dan Harmoni Kontribusi Disiplin Diri Bagi Pengembangan Pendidikan Kristen" (2021). https://osf.io/frsnz/.

. "EXEMPLARY: Menemukenali Kunci Pendidikan Kristen Bagi Anak Dalam Keluarga Dan Pembelajaran Agama Di Sekolah" (2021). https://osf.io/bntrk/.

__ "Jabatan Gerejawi Dan Peran Perempuan Dalam Pelayanan Gereja” (2021). https://osf.io/jtcag.

__. "Stratifikasi Sosial Kepemimpinan Tradisional Dalam Dinamika Demokrasi Modern" (2021). https://osf.io/63yaj/. 